\title{
Is IT Risk? An Automated ApProAch to Explain THE EX ANTE UIP DEVIATIONS OF BRAZIL*
}

\author{
Alex Luiz Ferreira \\ University of Sao Paulo
}

The paper tests whether ex ante deviations from Uncovered Interest Rate Parity correspond to default risk premium. Using an automated model selection criteria and data for Brazil (from november 2001 until december 2007), we found that deviations are correlated with a measure of risk (the EMBI+). There is also evidence that these deviations can be explained and predicted by a set of fundamentals (such as the current account deficit as a percentage of the GDP and domestic inflation, for example). Insofar as some of these variables can be controlled by the government, the results suggest that economic policy is able to decrease risk.

JEL: F36, F37, C52

Keywords: Uncovered Interest Rate Parity, Risk, Model Evaluation and Testing

\section{INTRODUCTION}

The efficient market hypothesis (under rational expectations) implies that the expectation, made at $t$, for the exchange rate prevailing at $t+n$, is equal to the forward exchange rate at $t$ for delivery at $t+n$. Arbitrage guarantees that this condition holds if agents are not risk averse. Otherwise, risk would drive a wedge between forward and expected spot rates. This wedge, assuming that Covered Interest Rate Parity holds, is equivalent to ex ante deviations from Uncovered Interest Rate Parity (UIP).

Engle (1996) asked whether the usual interpretation (and often assumption) that this wedge is risk can be regarded as true. If it is risk, he argues, then the wedge should vary according to the factors that are supposed to influence

\footnotetext{
* I acknowledge the invaluable support of the State of Sao Paulo research foundation FAPESP and of the University of Sao Paulo. I would like to thank, without implicating, Prof. Hans-Martin Krolzig and Prof. Lucio Sarno for comments on a earlier version of this paper. The paper also benefited from comments of participants at a seminar at the University of Kent. E-mail: alexferreira@usp.br.
} 
risk, such as economic fundamentals. This remark strongly influenced the present work, which aims to answer the questions: 1) do ex ante UIP deviations correspond to risk? 2) can ex ante UIP deviations be predicted by controlling for economic fundamentals?

There are many papers asking what the macroeconomic determinants of dollar-denominated bond spreads in emerging economies are. Edwards (1985), Edwards (1998), Ewing (2003), Nogués and Grandes (2001), Grandes (2007), Uribe and Yue (2006) and Tillmann (2004) are just a few examples. These papers provide the underlying specification of the model used in our tests. Our work complements this literature in an innovative way. We investigate whether ex ante UIP deviations (given by returns on uncovered bond spreads, instead of dollardenominated bond spreads), can be explained by economic fundamentals.

Our paper draws insights from a class of models, which suggest that risk depends on fundamentals, for example, studies that examine the determinants of debt crises in the 1980s and currency crises in the 1990s (see Krugman, 1979; Sachs, 1985; Obstfeld, 1996 and Kaminsky et al., 1998, for instance) and from papers like Bernhardsen (2000) and Knot \& de Haan (1995) that tested the relationship between nominal interest rate differentials and fundamentals. Our work also complements the extensive literature that investigates the forward exchange rate risk premium from the perspective of consumption-based models of risk (Hodrick, 1987 and Engel, 1996, for example, present surveys on the subject).

We ran a regression of ex ante UIP deviations ${ }^{1}$ against a measure of risk (the JPMorgan EMBI+) for Brazil. We also ran regressions of deviations against a set of economic fundamentals. The choice of country is due to Brazil's past history of debt default and also to availability of data on expected exchange rate changes. The sample period spans from 2001:11 until 2007:12 and the method used is the automated model selection criteria embodied in the algorithm of the econometric software PCGets. This tool seemed to be the most relevant for our purposes because, although the general unrestricted model (GUM) of the risk premium can be properly specified, the data generating process of the deviations is unknown. The lack of guidance from empirical papers on this specific subject, in addition to the great number of variables in the GUM, provide the reasons to use an algorithm that mechanizes and standardizes a series of complex search processes.

The findings of the paper have important implications for academics and policy-makers alike. Since deviations are explained by the EMBI+ and predicted by economic fundamentals, the assumption that an ex ante deviation is risk is reasonable. Other results found in the paper, regarding different signs or values of the parameters in comparison to what one would expect from theory, can also motivate further research. Insofar as some of the fundamentals can be controlled by the government, the suggestion for a policy maker is to focus on their manage-

\footnotetext{
1 Throughout the paper, we will refer to ex ante UIP deviations, alternatively, as: deviations, ex ante deviations and excess returns.
} 
ment, if the objective is to reduce excess returns and risk ${ }^{2}$. For example, Brazil has adopted an inflation targeting regime since 1999, which was effective in anchoring inflation and inflation expectations. According to the results of the paper, this improvement in the quality of the monetary instance reduced excess returns and risk. Other variables, such as the terms of trade could be improved by promoting the diversification of exports. The current account deficit as a proportion to GDP, which is a variable robust to the model specification, can be affected by an active trade policy, at least temporarily. These are examples of some fundamentals that appear to be correlated with excess returns and have the expected sign from economic theory.

The rest of the paper is organized as follows: we motivate the tests in the following section; then present the methodology (including an explanation about the automated process that is adopted). We discuss the data and the results in the fourth section and, finally, we conclude.

\section{Motivation}

Ex ante deviations from UIP seem to be the rule rather than the exception. The most common explanation is that the deviation is a compensation for agents to bear the possibility of the country's default. The reason might be related to the strength of the assumption of perfect asset substitutability or, alternatively, to the assumption of riskless bonds that underlies UIP. The former assumption seems to be too strong because, as countries' institutions and fundamentals differ, the default probabilities are also likely to vary. On the other hand, it is difficult to abandon the hypothesis of rational expectations. Transaction costs are thought to change only infrequently and, thus, would be unable to explain time-varying deviations from UIP.

UIP is a cornerstone of international finance literature. The version that includes risk is broadly used in economic modeling, for instance, in portfolio models. The relaxation of the perfect asset substitutability assumption results in an interest rate differential that can exist indefinitely, because the supply of assets is not perfectly elastic. Models of intertemporal maximization under uncertainty (see Obstfeld, 1996, chapter 5, for example) provide the microeconomic foundation for the allocation of resources under risk aversion. Investors choose their portfolios in such a way that the expected real returns in every asset, discounted by the intertemporal marginal rate of substitution, are equal in equilibrium. The concavity of the utility function can be a measure of risk aversion. It depends on the elasticity of substitution between goods, which can take some forms: CARA (constant absolute risk aversion) or the CRRA (constant relative risk aversion), for instance. The literature that models risk from this perspective usually estimates these

\footnotetext{
2 As predicted by the real interest rate parity hypothesis, risk is a prominent variable in determining both ex ante and ex post real interest rates. If lower real rates are a policy objective, the management of macroeconomic default risk is crucial.
} 
elasticities, or verifies whether the data is compatible with such models (see, for example, Cumby, 1987; Froot and Frankel, 1989, or Hodrick, 1987 for a survey). Engel (1996) concluded that the estimated elasticity is too high, i.e. investors are incredibly risk averse, and estimations are plagued with problems. We do not presume that deviations are risk; instead we test this hypothesis by employing a different methodology from the literature mentioned above.

In order to clarify and motivate our objective, suppose that $F_{t}$ is the forward rate for delivery at $t+1$ and that $S_{t+1}$ is the spot exchange rate prevailing during period $t+1$. Consider that $S_{t}$ represents the domestic price of the foreign currency and lower case variables, except interest rates, stand for their logarithms. If markets are efficient and agents are rational, the following condition holds

$$
f_{t}-\mathrm{E}_{t}\left(s_{t+1}\right)=r p_{t}^{r e}
$$

where $r p_{t}^{r e}$ corresponds to the rational expectations risk premium, as defined in Engel (1996). It is possible to show that $r p_{t}^{r e}$ is closely related to the UIP country risk premium. Speculation in the foreign exchange rate market guarantees

$$
i_{t}-i_{t}^{*}=\mathrm{E}_{t}\left(s_{t+1}\right)-s_{t}+\xi_{t}
$$

where $i_{t}$ is the domestic interest rate that matures at time $t+1$ and the asterisk correspond to the exogenously determined foreign interest rate. The letter E represents the expected value; the time subscript means that all information available at time $t$ was used to form the expectation. Finally, $\xi_{t}$ is the overall risk premium which corresponds to the sum of a country specific risk and a currency risk,

$$
\xi_{t}=\kappa_{t}+\rho_{t}
$$

where $\kappa_{t}$ is the political or country risk (reflecting a probability that the government will not pay the bond at maturity time) and $\rho_{t}$ is the exchange rate risk premium (which reflects the risks associated with exchange rate movements) ${ }^{3}$. We assumed that the covered interest differential is the "political" or country risk as below

$$
i_{t}-i_{t}^{*}=f_{t}-s_{t}+\kappa_{t} \text {. }
$$

Substituting (4) into (2) we have

$$
f_{t}-s_{t}=\mathrm{E}_{t}\left(s_{t+1}\right)-s_{t}+\xi_{t}-\kappa_{t}
$$

3 One can see Alper et al. (2007), and Chinn (2006) for a decomposition of risk. 
which, given (3), is equivalent to

$$
\begin{aligned}
& f_{t}-\mathrm{E}_{t}\left(s_{t+1}\right)=\rho_{t} \\
& r p_{t}^{r e}=\rho_{t}
\end{aligned}
$$

Engle (1996) wrote: "There would be evidence that $r p_{t}^{r e}$ is in fact a risk premium if the measure of $r p_{t}^{r e}$ were found to be determined by the economic variables to which theory says it should be related" (p. 130). Hence, if deviations

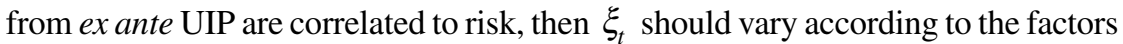
that are supposed to influence it, such as economic fundamentals. This hypothesis is tested in section 4 of the paper.

\section{Methodology}

Excess returns can thus be written as

$$
\xi_{t}=i_{t}-i_{t}^{*}-\left(\mathrm{E}_{t}\left(s_{t+1}^{e}\right)-s_{t}\right)
$$

A great number of authors found that $\xi_{t}$ follows an autoregressive process

$$
\left(1-\sum_{j=1}^{T} \beta_{j} L^{j}\right) \xi_{t}=\alpha+\mu_{t}
$$

where $L$ is the lag operator, $j$ is the number of lags, $T$ is the order of the autoregressive term, $\alpha$ is an intercept term, $\beta_{j}$ are the autoregressive parameters and $\mu_{t}$ is a random error that follows the classical properties. Ex ante deviations from UIP, $\xi_{t}$, could stem from transaction costs, imperfect information, Peso problems, bubbles etc. However, as stated above, the majority of works attribute $\xi_{t}$ to a risk premium. If $\xi_{t}$ is a risk premium, $\mu_{t}$ is also white-noise (in other words, agents have rational expectations) and, according to the literature of dollar-denominated bond spreads, we can write

$$
\xi_{t}=\alpha+\left(\sum_{j=1}^{T} \beta_{j} L^{j}\right) \xi_{t}+\sum_{i=1}^{F} \varphi^{i} f_{t}^{i}+\mu_{t},
$$

where $f^{i}$ is the $i^{\text {th }}$ fundamental and $\varphi^{i}$ is the associated coefficient; $F$ is the number of fundamentals in the GUM. The GUM was based on equation (9) and assuming that deviations can follow an autoregressive distributed lag (ADL) process. The implicit test assumption is that the linear combination of fundamentals can be a proxy for risk. 
An application of the Gets algorithm can be found in Krolzig and Hendry (2004) and an evaluation of alternative approaches for model selection is in Hendry \& Krolzig (2003). We considered this method to be appropriate because it released us from manually testing a great number of models using a general to specific $t$ or F-test. We were also able to use a standardized testing procedure and benefited from the rigor of the "theory of reduction". The procedure consists in selecting a congruent model, in other words, one that is absent of mis-specification (see PcGets, 2005). Monte Carlo experiments show that PcGets recovers the data generation process (DGP) with an accuracy close to what one would expect if the specification was known a priori (Hendry and Krolzig, 2003; Hendry \& Krolzig, 2005). This will be true, provided that the GUM contains the variables that matter to the DGP. Our tests were performed using the built in "liberal" strategy with automatic outlier correction. Hence, the algorithm is programmed to keep the maximum number of variables that matter to the DGP and to automatically correct for outliers (see Hendry and Krolzig, 2005 for a detailed description of the procedure).

In order to avoid endogeneity of the regressors, we tested the model in (9) using the following specification

$$
\xi_{t}=\alpha+\left(\sum_{j=1}^{T} \beta_{j} L^{j}\right) \xi_{t}+\sum_{i=1}^{F} \varphi^{i} f_{t-1}^{i}+\mu_{t}
$$

Note that contemporaneous variables were excluded from (10), hence, one can consider that we are following a type of an "in sample" forecasting strategy. It follows that the conditional forecast of $\mathrm{E}_{t}\left(\xi_{t+h}\right)$, for $h=1,2, \ldots, \infty$ can be expressed as $\mathrm{E}_{t}\left(\xi_{t+h}\right)=\alpha+\left(\sum_{j=0}^{T} \beta_{j} L^{j}\right) \mathrm{E}_{t}\left(\xi_{t}\right)+\varphi^{i} \mathrm{E}_{t}\left(f_{t+h-1}^{i}\right)$. Hence, our findings can reveal which fundamentals are able to predict UIP deviations. Although

our model selection criteria is rigorous, our forecasting strategy is simple. Out of sample forecasts of ex ante UIP deviations could be subject of investigation for future works (for example, an investigation along the lines of Clarida et al., 2003). Finally, it is important to note that, when the forecast horizon grows, the conditional forecast of ex ante deviations can be written as the limit of $\mathrm{E}_{t}\left(\xi_{t+h}\right)$ when $h \rightarrow \infty$, which is given by

$$
\bar{\xi}=\frac{\alpha+\sum_{i=1}^{F} \varphi^{i} \bar{f}^{i}}{1-\sum_{j=1}^{T} \beta_{j} L^{j}}
$$

where $\bar{f}^{i}$ correspond to the long run equilibrium of the $i^{\text {th }}$ fundamental (we are implicitly assuming that all $f^{i}$ variables are stationary). The unconditional mean expressed in (11) provides interesting information regarding the equilibrium risk and whether the economy is riskier than what its long-run mean suggests. 


\section{DATA}

We collected data on economic fundamentals, actual exchange rates and interest rates from the Institute of Applied Economic Research (IPEA), which is part of the Brazilian Planning Ministry (http://www.ipeadata.gov.br/). Data from exchange rate surveys was obtained from the Brazilian Central Bank (http://www. bcb.gov.br/). The sample period is restricted due to the availability of exchange rate survey data. The period spans from 2001:11 and 2007:12, hence, the number of observations is 74 .

The variable $i_{t}$, the nominal interest rate of Brazil (Selic), was transformed into a three-month rate (in order to be compatible with $i_{t}^{*}$, for which we used the three month maturity Treasury Bill of the US). The expected change in the exchange rate (consistent with the interest rate of month $t$ ) was calculated as difference between the average of the daily forecasts during month $t$ for month $t+3$ minus the spot rate at $t$. The EMBI+ (Emerging Markets Bond Index Plus), the annual spread between a dollar-denominated asset from Brazil and its corresponding North American counterpart, was also transformed into a quarterly rate. Daily data was taken from the internet site Cbonds (www.cbonds.info). We divided the annual EMBI+ by 1000 in order to obtain a percentage measure comparable to the deviations from UIP, and then calculated the quarterly EMBI+.

Following the literature, we employed economic fundamentals that are able to reflect liquidity and solvency problems, developments in the real and monetary sectors of the economy, international shocks and contagion. Table 1 shows the variables that were used to control for the fundamentals, their descriptions, expected signs and a brief explanation of the reasons underlying the expected signs of the estimated $\varphi_{i}$ parameters. The explanations are based upon arguments that, we suppose, one could find reasonable. However, there could be other explanations and different expected signs. The bottom line is that the significance and signs of the coefficients are an empirical matter, which is the line of investigation that we followed in this paper.

Some notes are worth taking in what regards the variables with unknown signs in Table 1 . The sign of capacity utilization is ambiguous because it might depend on the position of the economy in the business cycle. If it is above potential output, an increase in the utilization of the industry in Sao Paulo state might imply a higher probability of inflation and supply bottlenecks. On the other hand, if it is below potential output, the increase can be associated with a better use of the economy's inputs, which enlarges income and economy's ability to pay for its bonds at maturity time. Regarding this variable, we also have to explain that it was seasonally adjusted using monthly seasonal dummies.

The rationale for the terms of trade measure is that if export prices increase relative to import prices, then there is more revenue accruing from international trade and one would expect a decrease in both the country and currency risk. However, if export prices increase, the economy becomes less competitive and exports will be harder to sell. The final effect depends upon the price elasticities of demand and is an empirical issue. 
TABLE 1

CONTROL VARIABLES AND EXPECTED SIGNS

\begin{tabular}{|c|c|c|c|c|}
\hline Variable & Description & Control for: & $\begin{array}{l}\text { Expected } \\
\text { Sign }\end{array}$ & $\begin{array}{c}\text { Explanation } \\
\text { (ceteris paribus) }\end{array}$ \\
\hline $\begin{array}{l}\text { Current account } \\
\text { deficit to GDP } \\
\text { ratio }\end{array}$ & $\begin{array}{l}\text { Current account } \\
\text { deficit of the } \\
\text { previous } 12 \\
\text { months divided by } \\
\text { GDP. }\end{array}$ & $\begin{array}{l}\text { Liquidity } \\
\text { and Solvency } \\
\text { problems }\end{array}$ & Positive & $\begin{array}{l}\text { An increase in the } \\
\text { current account } \\
\text { deficit to GDP ratio } \\
\text { enlarges foreign } \\
\text { obligations. }\end{array}$ \\
\hline $\begin{array}{l}\text { Public deficit to } \\
\text { GDP ratio }\end{array}$ & $\begin{array}{l}\text { The first } \\
\text { difference of the } \\
\text { total public debt } \\
\text { to GDP ratio. }\end{array}$ & $\begin{array}{l}\text { Liquidity } \\
\text { and Solvency } \\
\text { problems }\end{array}$ & Positive & $\begin{array}{l}\text { Indicative measure } \\
\text { of the health of the } \\
\text { public accounts }\end{array}$ \\
\hline $\begin{array}{l}\text { Ratio of imports } \\
\text { to total foreign } \\
\text { exchange reserves }\end{array}$ & $\begin{array}{l}\text { Monthly imports } \\
\text { divided by total } \\
\text { reserves. }\end{array}$ & $\begin{array}{l}\text { Liquidity } \\
\text { and Solvency } \\
\text { problems }\end{array}$ & Positive & $\begin{array}{l}\text { More foreign } \\
\text { currency is needed to } \\
\text { pay for imports when } \\
\text { the variable rises. }\end{array}$ \\
\hline $\begin{array}{l}\text { Capacity } \\
\text { Utilization }\end{array}$ & $\begin{array}{l}\text { Percentage of } \\
\text { potential output } \\
\text { used by industry } \\
\text { in São Paulo state. }\end{array}$ & Real Sector & Unknown & $\begin{array}{l}\text { It depends on the } \\
\text { position of the } \\
\text { economy in the } \\
\text { business cycle. }\end{array}$ \\
\hline $\begin{array}{l}\text { Real rate of } \\
\text { growth of M4 }\end{array}$ & $\begin{array}{l}\text { The growth of } \\
\text { M4 divided by a } \\
\text { consumer price } \\
\text { index. }\end{array}$ & $\begin{array}{l}\text { Quality of the } \\
\text { Monetary Stance }\end{array}$ & Unknown & $\begin{array}{l}\text { The growth means, } \\
\text { ceteris paribys, } \\
\text { higher inflation and } \\
\text { higher liquidity. }\end{array}$ \\
\hline Domestic inflation & $\begin{array}{l}\text { Consumer price } \\
\text { inflation. }\end{array}$ & $\begin{array}{l}\text { Quality of the } \\
\text { Monetary Stance }\end{array}$ & Positive & $\begin{array}{l}\text { Higher probability } \\
\text { of a Balance-of- } \\
\text { Payments crisis, } \\
\text { structural problems } \\
\text { in government } \\
\text { finances and public } \\
\text { dissatisfaction that } \\
\text { may raise political } \\
\text { instability. }\end{array}$ \\
\hline $\begin{array}{l}\text { Rate of change of } \\
\text { the terms of trade }\end{array}$ & $\begin{array}{l}\text { Growth rate of the } \\
\text { ratio of export to } \\
\text { import prices. }\end{array}$ & $\begin{array}{l}\text { International } \\
\text { Shocks }\end{array}$ & Unknown & $\begin{array}{l}\text { A rise means that } \\
\text { more revenue is } \\
\text { accruing from } \\
\text { international trade. } \\
\text { On the other hand, } \\
\text { the economy } \\
\text { becomes less } \\
\text { competitive and } \\
\text { exports will be } \\
\text { harder to sell. }\end{array}$ \\
\hline US inflation & $\begin{array}{l}\text { Annual change } \\
\text { of the CPI in } \\
\text { percentage. }\end{array}$ & $\begin{array}{l}\text { International } \\
\text { Shocks }\end{array}$ & Positive & $\begin{array}{l}\text { Worsening in overall } \\
\text { risk. }\end{array}$ \\
\hline US unemployment & $\begin{array}{l}\text { Percentage of the } \\
\text { unemployed in the } \\
\text { workforce. }\end{array}$ & $\begin{array}{l}\text { International } \\
\text { Shocks }\end{array}$ & Positive & $\begin{array}{l}\text { Worsening in the } \\
\text { foreign demand. }\end{array}$ \\
\hline
\end{tabular}


TABLE 1

CONTROL VARIABLES AND EXPECTED SIGNS (cont.)

\begin{tabular}{|c|c|c|c|c|}
\hline Variable & Description & Control for: & $\begin{array}{l}\text { Expected } \\
\text { Sign }\end{array}$ & $\begin{array}{c}\text { Explanation } \\
\text { (ceteris paribus) }\end{array}$ \\
\hline $\begin{array}{l}\text { US real stock } \\
\text { index ( } \% \text { change) }\end{array}$ & $\begin{array}{l}\text { Dow Jones Index } \\
\text { deflated }\end{array}$ & $\begin{array}{l}\text { International } \\
\text { Shocks }\end{array}$ & Negative & $\begin{array}{l}\text { Improvement in the } \\
\text { foreign demand. }\end{array}$ \\
\hline $\begin{array}{l}\text { Level of EMBI + } \\
\text { Argentina }\end{array}$ & $\begin{array}{l}\text { The monthly } \\
\text { average of } \\
\text { the EMBI+, } \\
\text { calculated using } \\
\text { daily data. }\end{array}$ & Contagion & Unknown & $\begin{array}{l}\text { Cross-country } \\
\text { transmission of } \\
\text { shocks or the } \\
\text { spillover effects. }\end{array}$ \\
\hline $\begin{array}{l}\text { Level of EMBI + } \\
\text { Mexico }\end{array}$ & $\begin{array}{l}\text { The monthly } \\
\text { average of } \\
\text { the EMBI+, } \\
\text { calculated using } \\
\text { daily data. }\end{array}$ & Contagion & Unknown & $\begin{array}{l}\text { Cross-country } \\
\text { transmission of } \\
\text { shocks or the } \\
\text { spillover effects due } \\
\text { to financial, real and } \\
\text { political links. }\end{array}$ \\
\hline $\begin{array}{l}\text { Variance of } \\
\text { EMBI+ Argentina }\end{array}$ & $\begin{array}{l}\text { The monthly } \\
\text { variance of } \\
\text { the EMBI+, } \\
\text { calculated using } \\
\text { daily data. }\end{array}$ & Contagion & Unknown & $\begin{array}{l}\text { Cross-country } \\
\text { transmission of } \\
\text { shocks or the } \\
\text { spillover effects due } \\
\text { to financial, real and } \\
\text { political links. }\end{array}$ \\
\hline $\begin{array}{l}\text { Variance of } \\
\text { EMBI+ Mexico }\end{array}$ & $\begin{array}{l}\text { The monthly } \\
\text { variance of } \\
\text { the EMBI+, } \\
\text { calculated using } \\
\text { daily data. }\end{array}$ & Contagion & Unknown & $\begin{array}{l}\text { Cross-country } \\
\text { transmission of } \\
\text { shocks or the } \\
\text { spillover effects due } \\
\text { to financial, real and } \\
\text { political links. }\end{array}$ \\
\hline $\begin{array}{l}\text { Variance of } \\
\text { EMBI+ Brazil }\end{array}$ & $\begin{array}{l}\text { The monthly } \\
\text { variance of } \\
\text { the EMBI+, } \\
\text { calculated using } \\
\text { daily data. }\end{array}$ & $\begin{array}{l}\text { Conditional } \\
\text { Volatility }\end{array}$ & Positive & $\begin{array}{l}\text { Diversification away } \\
\text { from Brazilian bonds } \\
\text { occurs when variance } \\
\text { of returns increases. }\end{array}$ \\
\hline
\end{tabular}

The contagion variables that were chosen are supposed to reflect the broad definition of contagion. According to the World Bank, contagion is the cross-country transmission of shocks, or the spillover effects which can take place during both tranquil and crises periods. The restrictive definition is the transmission of shocks beyond any fundamental link among the countries, usually explained by herding behavior. The fundamental links among countries that can explain contagion are: financial, real and political links. One would expect the contagion to be positive because the economies in Latin America are similar in many ways. For example, a negative shock in one country causes an agent to increase reserves by selling assets from the countries that are still unaffected by the initial shock. However, it could induce diversification if links are weak, shocks are country specific or economies are not so similar in the way they respond to these shocks. Hence, the expected sign is unknown. Real links are usually associated with international trade, 
for which the real exchange rate and terms of trade are thought to be important, or variables such as foreign direct investment. There are political links when a country belongs to an association, an exchange rate arrangement, or a geographical region that share common characteristics.

As can be seen in Table 1, we have 15 repressors' in the test equation. We also added a constant, a time trend and the lag of the dependent variable for a dynamic GUM without the contemporaneous explanatory variables; hence there are $2^{18}$ sub-models and 18 ! possible search paths. It follows that there is a computational burden for undertaking the general to specific approach that would be impractical without the automated processes. In fact, the complications are much higher in one of the models because we also consider a specification with 4 lags (excluding the contemporaneous variables).

The GUM was specified for $\mathrm{I}(0)$ variables: many variables are in real growth rates and as a percentage of the GDP. In any case, a time trend was included in order to account for a deterministic trend. There are several other variables which could also be included in the GUM. For example, export growth, investment to GDP ratio and net capital inflows. As we believe that they were already been controlled by the variables that we had chosen, they would only have raised concerns about multicollinearity.

\section{RESUlts}

We first performed a Dickey-Fuller unit root test on $\xi_{t}$ which retrieved a statistic equal to -3.12 , which is significant at $5 \%$, thus rejecting the null of a unit root. There was no need to add lags of the dependent variable (i.e. an ADF was not necessary) since the estimated DF model is dynamically complete. In order words, the estimated model does not present serial correlation in the residuals. The autoregressive root is 0.77 resulting in an estimated unconditional mean equal to 1.96 that is significant at conventional levels. This result indicates that the quarterly equilibrium return on a uncovered asset from Brazil is $1.96 \%$ higher than its North American counterpart.

Furthermore, we tested whether ex ante deviations from UIP and EMBI+ are related by running the regression below

$$
\xi_{t}=\gamma_{0}+\gamma_{1} E M B I_{t}+v_{t}
$$

where $\gamma_{0}$ and $\gamma_{1}$ are parameters and the variable $v_{t}$ represents a white-noise error. Visual inspection of both variables in Graph 1 indicate that they are correlated. As a matter of fact, the correlation coefficient is 0.646. Ordinary Least Squares (OLS) estimation of (12) results in

$$
\xi_{t}=\underset{(0.652)}{-2.119}+\underset{(0.358)}{2.577 \mathrm{EMBI}_{t}}
$$


GRAPH 1

EMBI+ AND EXCESS RETURNS FOR BRAZIL
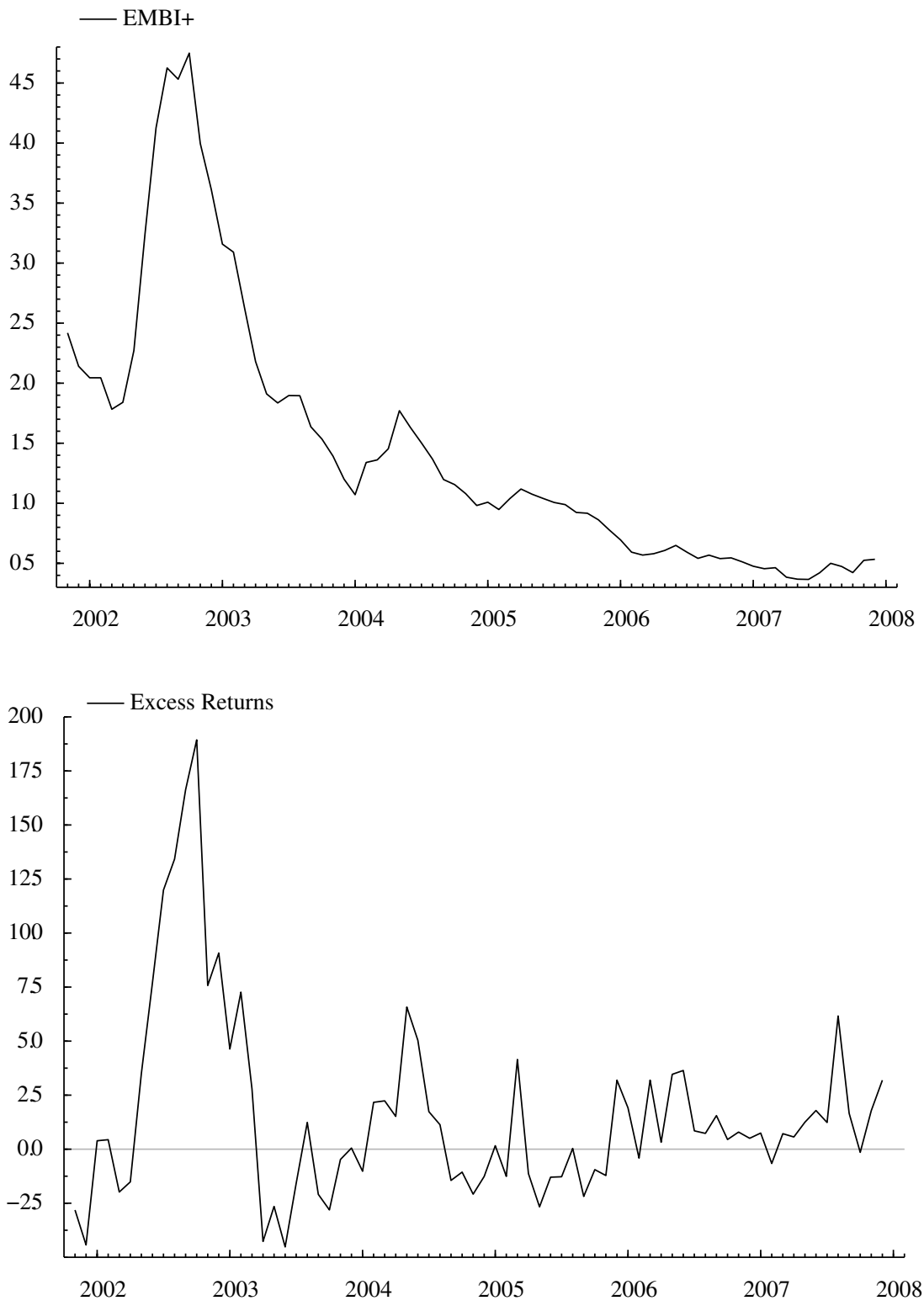

Source: www.cbonds.info and Institute of Applied Economic Research (IPEA). 
where standard errors are in parenthesis. The estimated parameters (which are significant at $1 \%$ ) show that, accounting for a negative constant, ex ante deviations and EMBI+ are positively related. The constant term, $\gamma_{0}$, was supposed to be zero and the slope parameter, $\gamma_{1}$, equal to one. Hence, parameters are of the wrong value, indicating either that the relationship between deviations and EMBI+ are not as we think, or that we need to control for other variables. From equation (3), one can see that the overall risk is split into two parts, the risk associated with exchange rate fluctuation and the default risk. We conclude that part of the ex ante UIP deviation is the default risk, since the other type of risk is not embedded in a dollar-denominated bond spread.

The basic GUM includes the first lag of all variables, including the lag of $\xi_{t}$, as explanatory variables, in addition to a constant and a time trend. Table shows that the lag of the dependent variable, the level of Mexican EMBI+, the variance of Brazil EMBI+, terms of trade, domestic inflation, current account and public deficit both as a percentage of the GDP, US unemployment and the percentage change in the US stock index all enter the final model. However, the final selection is not congruent as the residuals did not pass the autocorrelation test. When we increased the number of lags of the dependent variable to two, the serial correlation problem was eliminated and the model became congruent at $5 \%$.

TABLE 2

GETS ESTIMATION OF EQUATION (9)

The dependent variable is $\xi \mathrm{t}$

\begin{tabular}{lrcc}
\hline & Coefficient & Std. Error & t-prob \\
\hline$\xi_{\mathrm{t}-1}$ & 0.46 & 0.11 & 0.000 \\
EMBI+ Mexico & -2.65 & 0.96 & 0.001 \\
Variance EMBI+ Brazil & 1.66 & 0.42 & 0.000 \\
Terms of trade (\% change) & 0.09 & 0.15 & 0.511 \\
Domestic Inflation & 0.93 & 0.85 & 0.278 \\
Current account deficit to GDP ratio & 0.68 & 0.27 & 0.017 \\
Public deficit to GDP ratio & -0.22 & 0.32 & 0.494 \\
US unemployment & 0.96 & 0.32 & 0.004 \\
US real stock index (\% change) & -0.17 & 0.09 & 0.059 \\
\hline$n=73 R^{2}: 0.73$ & & & \\
\hline & & & \\
\hline AR 1-5 test: & $\mathrm{F}(5,59)=$ & 3.986 & {$[0.003]$} \\
ARCH 1-5 test: & $\mathrm{F}(5,54)=$ & 0.851 & {$[0.519]$} \\
Normality: & $\chi^{2}(2)=$ & 2.510 & {$[0.285]$} \\
Heteroscedasticity: & $\mathrm{F}(54,9)=$ & 1.039 & {$[0.519]$} \\
RESET: & $\mathrm{F}(1,63)=$ & 0.294 & {$[0.589]$} \\
\hline
\end{tabular}


TABLE 3

GETS ESTIMATION OF EQUATION (9) WITH ADDED DYNAMICS

The dependent variable is $\xi_{\mathrm{t}}$

\begin{tabular}{lrcc}
\hline & Coefficient & Std. Error & t-prob \\
\hline EMBI+ Argentina & 0.08 & 0.03 & 0.006 \\
EMBI+ Mexico & -10.33 & 1.91 & 0.000 \\
Variance EMBI+ Brazil & 3.46 & 0.49 & 0.000 \\
Current account deficit to GDP ratio & 3.03 & 0.49 & 0.000 \\
Public deficit to GDP ratio & -1.24 & 0.28 & 0.000 \\
US Inflation & 1.17 & 0.49 & 0.019 \\
US unemployment & 2.81 & 0.50 & 0.000 \\
\hline
\end{tabular}

$n=70 R^{2}: 0.74$

Diagnostic Tests

\begin{tabular}{lrrr}
\hline AR 1-5 test: & $\mathrm{F}(5,56)=$ & 1.429 & {$[0.228]$} \\
ARCH 1-5 test: & $\mathrm{F}(5,51)=$ & 1.326 & {$[0.268]$} \\
Normality: & $\chi^{2}(2)=$ & 8.001 & {$[0.018]$} \\
Heteroscedasticity: & $\mathrm{F}(18,42)=$ & 0.855 & {$[0.629]$} \\
RESET: & $\mathrm{F}(1,60)=$ & 0.596 & {$[0.443]$} \\
\hline
\end{tabular}

Note: We present the static long-run solution of the model -as in equation (10)-selected from a GUM with 4 lags.

Regarding the signs of the parameters, the result was surprising with regards to the public account deficit to GDP ratio and, to a lesser extent, the level of Mexican EMBI+. The negative sign of the Mexican EMBI+ might imply that both economies are not as similar as commonly thought and that a rise in the risk of Mexico induces diversification towards Brazilian bonds, thus increasing their price and reducing the corresponding interest rate spread. The finding concerning the public deficit remains a puzzle that lacks an explanation and requires further investigation. All other parameters are of the sign that one would expect from economic theory.

We added more dynamics in the second GUM of Brazil (see Table 3) by including four lags for each variable. For exhibition purposes, we present the static long run equation according to equation (11). Table 3 shows that the variables selected are: the level of the Argentinean and Mexican EMBI+; the variance of Brazil EMBI+; current account deficit to GDP ratio; the public deficit as a proportion of the GDP; US inflation and US unemployment. Note that both the constant and the time trend were excluded from the final selection, indicating that the majority of the variation in the deviations do not come from systematic components. There remains the problem of normality in the residuals, but no dummy was selected when 
we decreased the size of the marginal outlier ${ }^{4}$. An explanation is that our sample period excludes the large shocks of the financial crises in the 1900s. Extending the sample period in the future could change these results. For example, the current financial crisis implies not only in the deterioration of domestic and foreign fundamentals, but could also be reflected in an outlier. Until the moment the paper is written, however, there is no evidence in that respect.

The finding of the variance of the EMBI+, current account deficit as a percentage of the GDP and US unemployment with expected signs are robust to the specification of the model. Hence, these variables can be helpful in explaining and predicting UIP deviations. This result is interesting both for academics and policymakers. For the former because one can be confident in assuming that, at least partially, the deviations from UIP correspond to a risk premium. Our results also imply that more research is needed to explain the other components of deviations. For the latter, the findings signify that, for a given expected exchange rate, a reduction in the current account deficit and the smoothing of returns on dollar-denominated bonds of Brazil could help to decrease conditional risk, thus reducing nominal interest rates. For a given expected rate of inflation, such a policy also means reducing ex ante real interest rates.

\section{Conclusions}

We tested whether excess returns - or ex ante deviations of UIP - were related to risk premium by drawing insights from papers like Bernhardsen (2000) and Knot and de Haan (1995), who tested the relationship between nominal interest rate differentials and fundamentals and also from the works that investigated the determinants of dollar-denominated bond spreads (Edwards, 1985).

We constructed a measure of excess returns for Brazil, using data from exchange rate expectations from the Brazilian Central Bank. For the period that spans from 2001M11 until 2007M12, we first ran a regression of the excess returns against the EMBI+ and found that both variables are correlated with the expected sign. However, the size of the estimated parameters are different from what was expected, indicating that more research is needed if one wants to unveil all the determinants of ex ante deviations. We also tested whether a set of economic fundamentals was helpful in explaining excess returns. Our results show that $e x$ ante deviations can be predicted by economic fundamentals. The finding that the variance of EMBI+, current account deficit as a percentage of the GDP and US unemployment can predict deviations with the expected signs is robust to the specification of the model.

From a theoretical point of view, our results indicate that part of the UIP excess return corresponds to risk. Our paper helped to clarify the main determinants

\footnotetext{
4 The size of the marginal outlier is defined according to the area under the normal distribution that gives the probability of a "rare event". In the liberal strategy it is set to be 2.56 , which gives a probability of $1 \%$.
} 
of excess returns. This allows for the design of the appropriate macroeconomic policies that are able to decrease risk and equilibrium real interest rates. From a policy making perspective, the improvement in the quality of the monetary policy, for example, has been beneficial for the decrease in excess returns, according to our results. Some of the variables that we found affecting excess returns are out of the control of policy makers. Foreign variables and the variance of EMBI+ are such examples. To a large extent, the terms of trade and the current account deficit are also out of control. However, policies aimed at enlarging and diversifying exports can be helpful in decreasing risk because of their effect on the foreign sector.

\section{REFERENCES}

Alper, C. E., O.P. Ardic, and S. Fendoglu (2007), "The economics of uncovered interest parity condition for emerging markets: a survey". MPRA Paper 4079, University Library of Munich, Germany, pp. 1-39.

Bernhardsen, T. (2000), "The relationship between interest rate diferentials and macroeconomic variables: A panel data study for european countries". Journal of International Money and Finance (19) 2, 289-308.

Chinn, M. D. (2006), "The (partial) rehabilitation of interest rate parity in the floating rate era: Longer horizons, alternative expectations, and emerging markets". Journal of International Money and Finance 25 (1), 7-21.

Clarida, R. H., L. Sarno, M.P. Taylor and G. Valente (2003), "The out-of-sample success of term structure models as exchange rate predictors: a step beyond". Journal of International Economics 60 (1), 61-83.

Cumby, R. E. (1987), "Is it risk? Explaining deviations from uncovered interest parity". Journal of Monetary Economics 22 (2), 279-299.

Edwards, S. (1985), "The pricing of bonds and bank loans in international markets: and empirical analysis of developing countries foreign borrowing". NBER Working Paper 1689, 1-39.

Edwards, S. (1998), "Interest rate volatility, contagion and convergence: An empirical investigation of the cases of Argentina, Chile and Mexico". Journal of Applied Economics 1(1), 55-86.

Engel, C. (1996), "The forward discount anomaly and the risk premium: a survey of recent evidence", Journal of Empirical Finance 3, 123-191.

Ewing, B. T. (2003), "The response of the default risk premium to macroeconomic shocks". The Quarterly Review of Economics and Finance 43, 261-272.

Fama, E. (1984), "Forward and spot exchange rates". Journal of Monetary Economics 14, 319-338.

Froot, K. A. and J.A. Frankel, J. A. (1989), "Forward discount bias: Is it an exchange risk premium?". The Quarterly Journal of Economics 104 (1), 139-161.

Grandes, M. (2007), "The determinants of sovereign bond spreads: Theory and facts from Latin America". Cuadernos de Economía 44, 151-181.

Hendry, D. F. and H.-M. Krolzig (2003), "New developments in automatic general-tospecific modeling", in Econometrics and the Philosophy of Economics, in B.P. Stigum (ed.), MIT Press.

Hendry, D. F. and H.-M Krolzig (2005), “The properties of automatic gets modeling”. Economic Journal, Royal Economic Society 115 (502), 03., C32:C61. 
Hodrick, R. J. (1987), "The Empirical Evidence on the Eficiency of Forward and Futures Foreign Exchange Markets". Harwood Academic Publishers, New York.

Kaminsky, G., S. Lizondo and C. Reinhart (1998), "Leading indicators of currency crisis". IMF Staff Papers 45 (1), 1037-1047.

Knot, K. and J. de Haan (1995), "Interest rate differentials and exchange rate policies in Austria, the Netherlands, and Belgium". Journal of Banking and Finance 363-386.

Krolzig, H.-M. and D.F. Hendry (2004), "We ran one regression". Oxford Bulletin of Economics and Statistics 66 (12), 799-810.

Krugman, P. (1979), “A model of balance-of-payments crisis”. Journal of Money, Credit and Banking 11, 311-325.

Nogués, J. and M. Grandes (2001), "Country risk: Economic policy, contagion effect or political noise?". Journal of Applied Economics 4 (1), 125-162.

Obstfeld, M. (1996), "Models of currency crises with self-fulfilling features". European Economic Review 40 (3-5), 1037-1047.

Sachs, J. D. (1985), "External debt and macroeconomic performance in Latin America and East Asia". Brookings Papers on Economic Activity 2, 523-564.

Tillmann, P. (2004), "External shocks and the non-linear dynamics of brady bond spreads". Journal of International Financial Markets, Institutions \& Money 14, 439-454.

Uribe, M. and V. Yue (2006), "Country spreads and emerging countries: Who drives whom?”. Journal of International Economics 69, 6-36. 